\title{
Conciliar Christology and the Consistency of Divine Immutability with a Mutable, Incarnate God
}

\author{
Timothy Pawl \\ University of St. Thomas \\ Minneapolis, $M N$
}

\section{Introduction}

Consider THE SEVEN ecumenical councils that both Catholics and the Orthodox view as protected by the Holy Spirit and unrevisable in their teaching: two held at Nicaea (in 325 and 787), three held at Constantinople (in 381, 553, and 680-681), and one each at Ephesus (in 431) and Chalcedon (in 451). ${ }^{1}$ These councils, or a subset of them, enjoy some level of support from many Protestant groups as well. In fact, most confessional Protestant groups would be unwilling to part

I thank Matthews Grant, Michael Rota, and Mark Spencer for helpful comments on this article. I also thank the John Templeton Foundation for funding the Classical Theism Project, which I co-led with Dr. Gloria Frost. The discussions at the workshops hosted by that project also helped shape the results of this research.

1 For statements of the unrevisability of these councils according to the Catholic Church, see error 23 in the Syllabus of Errors promulgated by Pope Pius IX, in Heinrich Denzinger, The Sources of Catholic Dogma (hereafter, DH) (Fitzwilliam, NH: Loreto, 2002), no. 1723; and the Second Vatican Council's Dogmatic Constitution on the Church, Lumen Gentium, \$25. For Orthodox statements, see Hilarion Alfeyev, "The Reception of the Ecumenical Councils in the Early Church," St. Vladimir's Theological Quarterly 47, no. 3-4 (2003): 413-30; Alfeyev, Orthodox Christianity: Doctrine and Teaching of the Orthodox Church (Yonkers, NY: St.Vladimir's Seminary Press, 2012); Timothy Ware, The Orthodox Church (New York: Penguin Books, 1964), 28. 
ways with the theology of the first four ecumenical councils. ${ }^{2}$ These councils provide the bedrock of the orthodox and universal teaching on the Incarnation of the Second Person of the Trinity. Let us call the conjunction of claims made at these seven councils concerning the Christ "conciliar Christology."

Conciliar Christology teaches that Christ, being divine, is immutable. And yet, according to the same conciliar Christology, Christ, being man, changed. For instance, that immutable, divine Person went from being born, to being baptized, then crucified, and finally resurrected. How can this be? For it seems that nothing immutable can go from being one way to another, a point argued by many thinkers both recent and ancient. ${ }^{3}$ I have argued elsewhere

2 See, for instance, John Calvin, The Institutes of the Christian Religion, trans. Henry Beveridge (Grand Rapids, MI: Christian Classics Ethereal Library, 1845), IV, ch. 9, no. 8; the Anglican Church in North America, "Jerusalem Statement," no. 3, https://www.gafcon.org/resources/the-complete-jerusalem-statement; another statement form Anglican Church in North America website, http:// www.anglicanchurch.net/index.php/main/Theology/; and the Episcopal divine, Henry Percival, who wrote at the turn of the twentieth century, "I wish to declare in the most distinct manner that I accept all the doctrinal decrees of the Seven Ecumenical Synods as infallible and irreformable" (The Seven Ecumenical Councils of the Undivided Church [New York: The Christian Literature Company, 1900], ix). For more discussion of the councils and their authority among the different Christian groups, see Christopher Bellitto, The General Councils: A History of the Twenty-One General Councils from Nicaea to Vatican II (New York: Paulist Press, 2002); Joseph Kelly, The Ecumenical Councils of the Catholic Church: A History (Collegeville, MN: Liturgical Press, 2009), 64; John R. T. Lamont, "Determining the Content and Degree of Authority of Church Teachings," The Thomist 72, no. 3 (2008): 374-407; Norman Tanner, The Councils of the Church: A Short History (New York: Crossroad, 2001), 3-4, 7, 13; Christian Washburn, "St. Robert Bellarmine on the Infallibility of General Councils of the Church," Annuarium Historiae Conciliorum 42, no. 1 (2010): 171-92; Jordan Wessling, "Christology and Conciliar Authority," in Christology: Ancient \& Modern, ed. Oliver D. Crisp and Fred Sanders (Grand Rapids, MI: Zondervan, 2013).

3 For discussions of the logical compatibility of immutability and incarnation, as well as closely related discussions of the compatibility of incarnation with both impassibility and atemporality, see Douglas Blount "On the Incarnation of a Timeless God," in God and Time: Essays on the Divine Nature, ed. Gregory E. Ganssle and David M. Woodruff (Oxford: Oxford University Press, 2001), 236-48 (see also the other essays in this edited volume); Daniel Castelo, “Moltmann's Dismissal of Divine Impassibility: Warranted?" Scottish Journal of Theology 61, no. 4 (2008): 396-407; Richard Cross, The Metaphysics of the Incarnation:Thomas Aquinas to Duns Scotus (New York: Oxford University Press, 
that such reasoning from immutability to the denial of Incarnation is flawed. ${ }^{4}$ I have also, in the same place, gestured toward a metaphysics that could help us understand, to the extent that we are able, an immutable, incarnate God.

The goal of this article is to flesh out that initial understanding of incarnational immutability. The method I employ to attain this goal is to consider cases of predications from the texts of conciliar Christology. I show potential ontological truth conditions for those predications being true that do not require the truth conditions I propose for immutability to be unsatisfied. Put otherwise, I show ontological truth conditions for predications that imply Christ's mutability

2005), 215; Cross, "The Incarnation," in The Oxford Handbook of Philosophical Theology, ed. Thomas P. Flint and Michael Rea (New York: Oxford University Press, 2011), 452-75, at 464; Geoffrey Dunn, "Suffering Humanity and Divine Impassibility," Augustinianum 41, no. 1 (2001): 257-71; Dunn, "Divine Impassibility and Christology in the Christmas Homilies of Leo the Great," Theological Studies 62, no. 1 (2001): 71-85, Gilles Emery, O.P., "The Immutability of the God of Love," in Divine Impassibility and the Mystery of Human Suffering, ed. James F. Keating and Thomas Joseph White, O. P. (Grand Rapids, MI: Eerdmans, 2009), 27-76; Ronald Feenstra, "A Kenotic Christology of Divine Attributes," in Exploring Kenotic Christology, ed. C. Stephen Evans (Oxford: Oxford University Press, 2006), 139-64, at 142; Colin Gunton, "Time, Eternity and the Doctrine of the Incarnation," Dialog 21, no. 4 (1982): 263-68; Jonathan Hill, "Incarnation, Timelessness, and Exaltation," Faith and Philosophy 29, no. 1 (2012): 3-29; Richard Holland, God, Time, and the Incarnation (Eugene, OR: Wipf \& Stock, 2012); Adrio König, “The Idea of the 'Crucified God': Some Systematic Questions," Journal of Theology for Southern Africa 39 (1982): 55-61; Jürgen Moltmann, The Crucified God:The Cross of Christ as the Foundation and Criticism of Christian Theology (Minneapolis, MN: Fortress Press, 1973), 214-15; Moltmann, The Trinity and the Kingdom: The Doctrine of God (Minneapolis, MN: Fortress Press, 1993), 22-23; John O’Keefe, "Impassible Suffering? Divine Passion and Fifth-Century Christology," Theological Studies 58, no. 1 (1997): 39-60; T. Evan Pollard, "The Impassibility of God," Scottish Journal of Theology 8, no. 4 (1955): 353-64; Herbert Relton, A Study In Christology (London: Society for Promoting Christian Knowledge, 1917), 54; Thomas Senor, "Incarnation and Timelessness," Faith and Philosophy 7, no. 2 (1990): 149-64; Senor, "Incarnation, Timelessness, and Leibniz's Law Problems," in Ganssle and Woodruff, God and Time, 220-35; Richard Sturch, The Word and the Christ: An Essay in Analytic Christology (New York: Oxford University Press, 1991), 33-34, 100-106; Thomas Weinandy, Does God Change? The Word's Becoming in the Incarnation (Still River, MA: St. Bede's, 1985); and Frances Young, "A Cloud of Witnesses," in The Myth of God Incarnate, ed. John Hick (Philadelphia, PA: Westminster Press,1977), 13-47, at 27.

4 Timothy Pawl, In Defense of Conciliar Christology: A Philosophical Essay (Oxford: Oxford University Press, 2016). 
and Incarnation that are also consistent with the truth of "Christ is immutable." Since the truth conditions for the incarnational texts do not require the falsity of the claim that "Christ is immutable," the incarnational claims do not require the rejection of immutability. In other words, the Incarnation is no reason to deny divine immutability, and vice versa.

In this article, I will defend neither the claim that God became man nor the claim that God is immutable. Similarly, I will not view myself as beholden to answer challenges to either claim on its own, such as challenges to the possibility of Incarnation regardless of whether God is immutable or not. No doubt, if such challenges succeed and the Incarnation is impossible, then any conjunction of claims including the Incarnation is impossible too. You cannot remove a contradiction by adding more propositions to it. Be that as it may, such objections are not my target in this article, though they have been my target elsewhere. ${ }^{5}$ Rather, I will target objections that begin with either Incarnation or immutability and say that the one rules out the other, that you cannot have both. ${ }^{6}$

5 For objections to immutability, see Timothy Pawl, "Divine Immutability," in The Internet Encyclopedia of Philosophy, ed. James Fieser and Bradley Dowden, 2009, iep.utm.edu/div-immu/. For objections to Incarnation, see Pawl, "A Solution to the Fundamental Philosophical Problem of Christology," The Journal of Analytic Theology 2 (2014): 61-85; Pawl, "Conciliar Christology and the Problem of Incompatible Predications," Scientia et Fides 3, no. 2 (2015): 85-106; Pawl, "Temporary Intrinsics and Christological Predication," in Oxford Studies in Philosophy of Religion, vol. 7, ed. Jonathan L. Kvanvig (Oxford: Oxford University Press, 2016), 157-89; Pawl, In Defense of Conciliar Christology; Pawl, "Truthmaking and Christian Theology," Proceedings of the American Catholic Philosophical Association 89 (2015): 181-94; and Timothy Pawl and Kevin Timpe, "Freedom and the Incarnation," Philosophy Compass 11, no. 11 (2016): 743-56.

6 It is a bit hard to spell out the exact sort of objections I am trying to rule out here. Consider the sentence to which this footnote is appended. It is not quite right. For, one could start with incarnation and rule out immutability as follows, if one thought incarnation were impossible. Begin with incarnation. That is contradictory. So anything follows from it. So the denial of immutability follows from it. Thus, incarnation rules out immutability. Such an objection is not the sort of objection I want to consider in this article. I want to consider objections that say, in a more straightforward sense, that something about incarnation rules out immutability, where that something is not mere contradiction in the concept of incarnation.

Likewise, one cannot simply begin by supposing that both incarnation and immutability are possible and then ask whether they are compossible. For, to many in the debate, God's nature is necessarily as it is. So, if divine immuta- 
I begin in my second section with a brief overview of the orthodox teaching of the immutability and Incarnation of Christ found in conciliar Christology. Then, in my third section, I present some interpretations of immutability. ${ }^{7}$ do all the preceding in order to stage my fourth section, which provides metaphysically illuminating ontological truth conditions for some predications found in conciliar Christology. In the fifth section, I generalize from the cases I consider in the previous, providing a general account of how to deal with predications truly said of Christ, according to conciliar Christology, in a way that does not impinge on divine immutability. Since the world could be set up, I argue, such that the truth conditions for both "Christ is immutable" and "Christ suffered before he died" are true, it is false that Christ's immutability, on conciliar Christology, implies his inability to become incarnate. And it is likewise false, then, that his Incarnation precludes his immutability.

\section{The Witness of Conciliar Christology}

The conciliar texts say that Jesus Christ is one person of the Holy Trinity and has two natures: the one divine nature shared by all three divine Persons; and a particular human nature, which the councils claim to be composed of body and soul. ${ }^{8}$ And, according to conciliar Christology, that human nature, the body and soul composite, has certain contingent features. For instance, Leo the Great, in his Tome to Flavian, which was accepted at the council of Chalcedon, states that the nature "was hung, pierced with nails." And again, the Church Fathers at Constantinople III write that "each nature wills and performs the things that are

bility were possible, it would be necessary. And if it is necessary, then God is immutable in every world, including the possible world(s) where incarnation occurs. So incarnation and immutability are compossible. Such an argument, again, misses the mark. It makes it too easy for the proponent of immutability and incarnation. My hope is that the reader can see what sort of objection I am after in this article.

7 For instance, see Pawl, "A Solution," "Conciliar Christology," In Defense of Conciliar Christology, and "Temporary Intrinsics."

8 For conciliar texts claiming that Christ is a person of the Trinity, see Norman P. Tanner, Decrees of the Ecumenical Councils (Washington, DC: Georgetown University Press, 1990), 5 and 86. For texts claiming that Christ had the two natures in question, see Tanner, Decrees, 41, 44, 69, and 86. For texts claiming that Christ had both a human body and a human soul, see Tanner, Decrees, 41, $44,55-56,69,86$, and 115. For discussion of this textual evidence, see Pawl, In Defense of Conciliar Christology, chs. 1-2 and section II.b.

9 Tanner, Decrees, 81. 
proper to it in a communion with the other." ${ }^{\prime 10}$ The conciliar authors, then, are not afraid to predicate certain contingent states and activities of the human nature itself. ${ }^{11}$

The human nature is "hypostatically united" to the divine nature in the person of the Son, is "assumed" by the person of the Son. ${ }^{12}$ That hypostatic union is itself ineffable, on conciliar Christology. ${ }^{13}$ We cannot exhaust an analysis of what it is, but we can understand what it does, at least in some circumstances. One thing it does is be that thing in virtue of which the two natures are truly united together in the person of Christ. In virtue of this true uniting, some true predications of the human nature are true also of the divine Person. For instance, because the human nature is hung, it is true to say of Christ, the person, that he is hung. This is the ancient doctrine of the "communication of idioms."

The texts of conciliar Christology teach that the Second Person of the Trinity, the Word, Jesus Christ, was immutable even in the context of his Incarnation. There are multiple texts that one could point to in support of this claim, but I will provide just two of them. ${ }^{14}$ First, Cyril, Patriarch of Alexandria and the chief mover at the Council of Ephesus, wrote in his Third Letter to Nestorius: ${ }^{15}$

10 Tanner, Decrees, 129.

11 This is true not only of the conciliar fathers but also of very many people in the tradition. For instance, Athanasius (see Khaled Anatolios, Athanasius [New York: Routledge, 2004], 70-72, 140), Cyril of Alexandria (see Bellito, The General Councils, 24, and Relton, The General Councils, 56), Pope Leo the Great (see Bronwen Neil, Leo the Great [New York: Routledge, 2009], 110), Martin Chemnitz (see The Two Natures in Christ [Saint Louis, MO: Concordia, 1971], 191, 216), and Thomas Aquinas all predicate of the human nature thus. Aquinas calls the assumed human nature visible (Summa theologiae [ST] III, q. 8, a. 1, ad 3), passible (ST III, q. 14, a. 1, ad 2), corporeally defective (ST III, q. 14 , a. 3 , ad 2), etc.

12 On assumption and hypostatic union being different, see Aquinas, ST III, q. 2, a. 8 .

13 Tanner, Decrees, 72, 117.

14 For a more thorough discussion of conciliar Christology's teaching of divine immutability, as well as the teaching of divine immutability in other confessional statements, see Pawl, "Divine Immutability," and In Defense of Conciliar Christology, 16-18, 181-84.

15 This letter was accepted at the Council of Ephesus, and so is part of conciliar Christology. For more on the interesting topic of the acceptance of this letter in ecclesial history, see Thomas Graumann, "'Reading' the First Council of Ephesus (431)," in Chalcedon in Context: Church Councils 400-700, ed. Richard Price and Mary Whitby (Liverpool, UK: Liverpool University Press, 2011), 
We do not say that his flesh was turned into the nature of the godhead or that the unspeakable Word of God was changed into the nature of the flesh. For he (the Word) is unalterable and absolutely unchangeable and remains always the same as the scriptures say. For although visible as a child and in swaddling cloths, even while he was in the bosom of the virgin that bore him, as God he filled the whole of creation and was fellow ruler with him who begot him. ${ }^{16}$

Here we see Cyril affirming that the person of the Word, the person who became incarnate, even while incarnate, was "unalterable and absolutely unchangeable."

In addition, Cyril writes in a letter to John of Antioch that was also accepted by conciliar Christology in the Definition of faith from the council of Chalcedon: ${ }^{17}$

God the Word, who came down from above and from heaven, "emptied himself, taking the form of a slave," and was called son of man, though all the while he remained what he was, that is God (for he is unchangeable and immutable by nature). ${ }^{18}$

Here we see that God the Word, the very same Person as Jesus Christ, while incarnate, remained God, being "unchangeable and immutable by nature."

Both of these texts teach that the Word became incarnate. Furthermore, both teach that, while incarnate, he was immutable. This is not merely a claim about the divine nature, as both texts make clear that the term is predicated of the incarnate person of the Word (that said, the divine nature is also called immutable on the same page as the immediately preceding quotation).

27-44, at 36; Edward R. Hardy, Christology of the Later Fathers (Philadelphia, PA: Westminster John Knox Press, 1954), 349; Edward Landon, A Manual of Councils of the Holy Catholic Church, 2 vols. (Edinburgh: John Grant, 1990), 1:201; Richard Price, "The Council of Chalcedon (451): A Narrative," in Price and Whitby, Chalcedon in Context, 76, 85; Price and Whitby, Chalcedon in Context, 11-22; Tanner, Decrees, 37-38; On the Person of Christ: The Christology of Emperor Justinian, trans. Kenneth Paul Wesche (Crestwood, NY: St.Vladimir's Seminary Press, 1997).

16 Tanner, Decrees, 51 (emphasis added).

17 Tanner, Decrees, 85.

18 Tanner, Decrees, 72 (the parenthetical is in Tanner's translation, but the added emphasis mine). 
How, then, might one understand immutability and Incarnation such that conciliar Christology is not contradicted and yet we have a stable metaphysical interpretation of how an immutable Christ can go from being one way to being another? In the next section I discuss multiple ways one might understand immutability.

\section{Some Understandings of Immutability}

To my mind, there are two errors to avoid when considering what these councils intend to teach when they teach that Christ is immutable. One view that I have argued against elsewhere is that immutability requires that anything immutable cannot in any way, in any fashion, no matter what, change. Call such a view super-duper immutability. On the other end of the spectrum, weak immutability can be understood as the view that the only sort of immutability that the divine Persons have is immutability with respect to moral constancy. ${ }^{19}$ Christ, then, in being immutable, is not fickle or morally inconstant. Weak immutability denies any stronger immutability of the person in question. In the following paragraphs, I argue that both of these views of immutability fail as an interpretation of the conciliar texts.

As an interpretation of the conciliar teachings, super-duper immutability is wrong-headed, as it is inconsistent with explicit teachings taught at every ecumenical council. Those teachings are included in the Nicene Creed, which states that Christ suffered, died, and was buried. Suffering, though, implies change, as does death. Thus, it is false that he did not change in any way, in any fashion, no matter what. The aptness conditions for being super-duper immutable, then, are not met by Christ, though they are met by the divine nature, since that thing, on conciliar Christology, cannot change in any way. Thus, super-duper immutability is not what the conciliar fathers intended to teach when, in the same texts, they taught that Christ was immutable.

Consider, then, weak immutability. It is no doubt true of Christ that he was morally constant. But weak immutability does not

19 For discussions of weak immutability, see Isaak Dorner, Divine Immutability: A Critical Reconsideration (Minneapolis, MN: Fortress Press, 1994); Jay W. Richards, The Untamed God:A Philosophical Exploration of Divine Perfection, Simplicity, and Immutability (Downers Grove, IL: IVP Academic, 2003), 198-99; Richard Swinburne, The Coherence of Theism (New York: Oxford University Press, 1993), 219; Robert R. Williams, "I. A. Dorner: The Ethical Immutability of God," Journal of the American Academy of Religion 54, no. 4 (1986): 721-38. 
capture the full intent the councils had when asserting that Christ was immutable. We can see this clearly if we reconsider the work the claim of immutability was put to in the councils. For instance, in the passage from Cyril's letter to Nestorius quoted above, he uses immutability as evidence for the falsity of the claim that the divine nature or the Word turned into a human nature, or vice versa. If immutability were only a claim to moral constancy, this would be a lousy inference, as moral constancy is insufficient as a reason for thinking that such transformations did not occur. ${ }^{20}$ Weak immutability, then, is also not what is being taught in the conciliar texts.

Elsewhere, I have provided what I call "revised truth conditions" for the predicate "immutable," suggesting that we ought to understand a thing's being immutable in the following sense: " $\mathrm{S}$ is immutable when S has a nature that is unable to change." 21 We can then give a similar understanding of mutability: "S is mutable when $\mathrm{S}$ has a nature that is able to change." This revised truth condition for immutability avoids the pitfalls of both the super-duper and the weak versions of immutability. Consider them in turn.

As we saw above, the super-duper understanding of immutability is at odds with the conciliar texts because it precludes Christ's going from, at an earlier point, being baptized to, at a later point, being crucified. The revised view, however, has no such implication. Christ can have a nature that is unable to change, which is the divine nature, and yet still have a nature that is able to change in the relevant ways, his human nature. Thus, he can be aptly characterized by both the predicates "mutable" and "immutable," on the revised truth condition.

Similarly, as we saw above, the weak view of immutability is at odds with the conciliar texts because it fails at supporting the inferences to which the fathers put the concept of immutability. The revised view, however, has no such difficulty. On this view, Christ's divine nature is precluded from being able to change. Thus, the following two inferences are comprehendible: (1) from divine immutability it follows that the Word cannot be changed into a human nature; (2) from divine immutability it follows that the divine nature

20 I make this argument in more detail in In Defense of Conciliar Christology, 108-9.

21 Pawl, In Defense of Conciliar Christology, 174. These truth conditions are "revised" from a standard contemporary interpretation of the term that does not include a reference to a nature of the entity in question. 
cannot be changed when the divine person assumes human nature.

Neither the super-duper nor the weak view of immutability, then, is a view that is consistent with the conciliar texts. In what follows, I will assume the revised truth conditions for immutability. I will not at every turn repeat that long phrase, "the revised truth conditions for immutability." Rather, I will simply suppose that the reader is keeping in mind the understanding of the terms I stipulate, with an occasional reminder here or there.

As I have presented the truth conditions for something's being immutable, they require that thing's having a nature that is unable to change. For the remainder of this article, then, I invite the reader to keep a hand atop the ontological buzzer. If I say something that implies that the divine nature goes from being one way to being another, push it. In having said such a thing, I will contradict my intention of providing an account of an immutable, incarnate person. In other words, the reader is invited to be on the lookout for any instance in which I deny, or say something that implies the falsity of, the super-duper immutability of the divine nature. ${ }^{22}$ (The divine nature fulfills the conditions for being super-duper immutable, even though the Second Person of the Trinity does not.)

My goal is to spell out the truth conditions of conciliar claims such that none of them require some change in the divine nature. If I can succeed in that, I can show that affirming the truths required for the Christian Incarnation story does not imply that the incarnate person was not immutable. Since that is the thesis that I wish to defend, I will have made my case.

\section{Incarnational Predications and Their Truth Conditions}

One useful way to proceed, which I will follow in this section, is by examples. After giving examples, I will move on in the next section to provide a general theory of how to go about answering challenges to the immutability of the Word that arise from incarnational claims that are part of conciliar Christology.

We can get a sense of the ways of understanding predications that are apt of Christ by looking at the things said of him in creedal statements from the ecumenical councils. Consider, for instance, the

22 The divine nature counts as having a nature that is unable to change in virtue of being a nature that is unable to change, and so fulfills the revised truth conditions for immutability as well. 
Nicene-Constantinopolitan Creed $^{23}$ (which is often called simply the Nicene Creed today, though it includes elements first introduced at Constantinople I). Here are thirteen things that council says of Christ that we can use as test cases to give an account of what sort of predications the Incarnation requires to be true: (1) Christ is the only-begotten Son of God; (2) Christ is born of the Father before all ages; (3) Christ is true God; (4) Christ is consubstantial with the Father; (5) Christ is creator of all things; (6) Christ came down from heaven; (7) Christ became man; (8) Christ was crucified; (9) Christ suffered; (10) Christ died; (11) Christ rose again; (12) Christ ascended into heaven; and (13) Christ will come again in glory. If these predications can all be true of something that fulfills the revised conditions for immutability, then it seems to me that we will have a good framework for determining how to deal with other objections that arise specifically from the conjunction of divine immutability and incarnation.

The first four predications are true of Christ without reference to the Incarnation. (The fifth is as well, but I save that claim for a separate discussion.) Even if Christ had not become incarnate, he would still be the only-begotten Son of God, born of the Father, true God, and consubstantial with the Father. Perhaps we could not say that Christ was born "before all ages" if there were no ages at all, and so that claim, as stated, requires there to be some temporal creation. Even still, temporal creation does not imply incarnation, and so this claim does not require the Incarnation to be true. Moreover, "prior to" need not be understood in a temporal sense. ${ }^{24}$ In fact, as we will

23 Tanner, Decrees, 24.

24 For some discussion of this point, see, for instance, St. Ignatius of Antioch in his Letter to Polycarp (see John R. Willis and M. J. Rouët de Journel, The Teachings of the Church Fathers [San Francisco: Ignatius Press, 2002], 343), Gregory the Theologian (see M. H. Alfeyev, Orthodox Christianity: Doctrine and Teaching of the Orthodox Church [Crestwood, NY: St. Vladimir's Seminary Press, 2012], 275), and St. Leo, who speaks of the Son, when becoming incarnate, beginning to exist in time, though remaining before time (ante tempora) (Tanner, Decrees, 79). For contemporary authors discussing the historical and systematic case for divine immutability, see M. H. Alfeyev, Orthodox Christianity, 142; Brian Daley, Gregory of Nazianzus (New York: Routledge, 2006), 133; Leo Davis, The First Seven Ecumenical Councils (325-787): Their History and Theology (Collegeville, MN: Liturgical Press, 1990), 49, 52; Ludwig Ott, Fundamentals of Catholic Dogma, 4th ed. (St. Louis, MO: Herder, 1960), 36-37; Joseph Pohle, God: His Knowability, Essence, and Attributes: A Dogmatic Treatise Prefaced by a Brief General Introduction to the Study of Dogmatic Theology (St. Louis, MO: B. Herder, 1911), 306-13; Eleonore Stump, The God of the Bible and the God of the Philosophers (Milwaukee, WI: Marquette University Press, 2016). 
see below, there is good reason from the Nicene Creed itself not to understand Christ's begetting from the Father in a temporal or mutable sense.

Some might argue that the content of the first four predications requires a mutable God. For, to be begotten, the claim goes, requires change. And to beget, which the Father does to the Son, requires change too. And to be begotten prior to something else requires a temporal difference. I think these claims are false. The authors were intent on theories of the divinity that included immutability. They did not take their understanding of the term "to be begotten" to imply "to be changed." In fact, they explicitly take up this very point in the Nicene Creed in an original anathema that was included in that first ecumenical creed of the Church:

And those who say "there once was when he was not," and "before he was begotten he was not," and that he came to be from things that were not, or from another hypostasis or substance, affirming that the Son of God is subject to change or alteration-these the catholic and apostolic church anathematises. $^{25}$

The goal here is to ward off interpretations of Christ's divine begetting that include change: from non-being to being, from before to after, or from contingent things as its source. It seems clear to me from this anathema that any reading of divine begetting that does require change is a reading the Fathers would vehemently reject. If the last sentences of a creed (these condemnations) explicitly rule out an interpretation of begetting, we should not force that very interpretation of begetting onto the first sentences of the creed. To do so is exegetically irresponsible.

Even still, suppose one were to argue that begetting necessarily requires change, whether the Fathers like or accept that or not. Let the Fathers say that their concept of "begetting" does not imply change until they are blue in the face; they will succeed no more than someone who reiterates continually that his concept "bachelor" does not imply being unmarried. Even if this objector were right and begetting does imply change of the divine nature, whether the Fathers like it or not, what this argument would show is not that

25 Tanner, Decrees, 5. 
there is a special contradiction lurking in the conjunction of an incarnation and the doctrine of divine immutability. For this alleged contradiction is neutral on whether or not Christ, in addition to being begotten by the Father, is also begotten by Mary. Rather, this conceptual argument that begetting requires change would show that the doctrine of the Trinity is incompatible with divine immutability. That is a different charge, one I am not on the hook for answering in this article, though I do see the importance of someone answering it.

Consider the fifth claim, that Christ is the creator of all things. This claim must be modified by some "except" clause. For he did not create himself or the other divine Persons. ${ }^{26}$ Many modify it by claiming that he created all non-divine things. Some who believe in non-divine, necessary entities except further, claiming that he did not create anything necessary, which might include platonic forms, propositions, or other types of abstract objects. We might say, in an attempt to be neutral to these different exception clauses, that the fifth predication tells us that some things are created and that anything that was, in fact, created was created by Christ. As parenthetically noted earlier, this claim neither precludes nor entails an incarnation.

Now, it might be that there is a contradiction lurking in conciliar Christology insofar as it requires Christ to create and be immutable. For, one might argue, creation requires change in the creator, and so a creator cannot be immutable. That, again, is a different sort of objection, one that I am not required to answer here, ${ }^{27}$ since it does not target or employ the Incarnation. ${ }^{28}$

26 Mark Spencer points out to me that perhaps these divine entities do not count as "things," and so do not fall under the domain of discourse here.

27 For discussion of such objections, I again point the reader to my "Divine Immutability" and ch. 8 of my In Defense of Conciliar Christology.

28 Yes, but suppose God is immutable. Creation is contingent. So, in some situation, you have an immutable God and creation, and in another possible situation, you have an immutable God and no creation. What explains why God creates in some situations and not in others? What explains his creating this and not that in any situation in which God does create? How can immutability and creation make sense?

In reply, look down. Do you see your feet? Do you see what they are resting on? It might look like carpet, or cement, or wood, or a sofa cushion. But it is really a cleverly disguised trail. You have been following it for some time now, you know.You may have passed Bugs on the way to Albuquerque, adeptly dodged a beast from Caerbannog, thumped with Thumper, etc. No doubt you are tired, and rightly so, after this prolonged escapade. Hop in. I will take you back to the main thoroughfare. 
Let us move on, then, to the remaining seven claims, which are not neutral with respect to incarnation. Each of these claims is an incarnational claim. Thus, each requires some explication of how an immutable person could do that. Such an explication must safeguard the super-duper immutability of the divine nature, the revised immutability and mutability of the divine Person, and the mutability of the human nature.

Consider the seven claims in order. Claim 6 from above is that Christ came down from heaven. Did that require any change on the part of his divine nature? I think it did not. We can give an ontological account of what happened in the following way. God created both the human nature and the hypostatic union itself. The hypostatic union is a created thing in virtue of which the Word assumes the human nature and unites it to himself hypostatically, in his person. For a divine person to "come down from heaven," at least in this context, is for that person to be thus united to a created nature. In creating the human nature and the particular hypostatic union that unites it to the divine nature in the person of the Word, God has brought it about that the truth conditions for "Christ came down from heaven" are fulfilled. And all this without our having to say or imply any change in the divine nature. Put otherwise, if an immutable thing can create at all, it can bring about the ontological conditions for the truth of the claim "Christ came down from Heaven."

Next, claim 7 is that Christ became man. What are the truth conditions for this assertion? To become anything, do I have to first exist and not be it, or is it enough for there to have been a time at which I was not it, even if I did not exist to be it at the time? Or perhaps no prior time is needed at all. Suppose God creates the universe to have an angel in it at the first instant. Did that being become an angel at that point? It does not matter for my purposes whether we understand "became man" in a way that allows the predicate to be apt of others (e.g., me) or not. But it would be good to have a case in which the term is said of Christ because he is human but cannot be said of any of us mere humans, even though we are human. So I will treat the predicate "became man" to require that whatever becomes man must exist as a non-man prior to (in some sense of "prior to") its becoming man.

Now, Christ did exist prior to his becoming a man. And then he began to have a human nature in the manner I spelled out above. That is, he began to fulfill the aptness conditions for the claim 
"Christ is man" in virtue of the creation of the hypostatic union and the assumed human nature. Again, as stated above, such fulfillment of the truth conditions does not require any change in the divine nature. The person changes in the acquisition of a human nature, since the person now, unlike previously (whether in eternity or in time), has a mass and shape. Moreover, that mass and shape continually change. That, though, is no problem on this view. For Christ to go from having a certain mass and shape to another mass and shape is for his assumed human nature to go from fulfilling the ontological conditions in which a person with that nature would be one shape to fulfilling the ontological conditions in which a person with that nature would be another shape, and similarly for mass. And those changes on the part of the assumed nature can all happen without the proponent of divine immutability having to say anything at all about the divine nature changing. So, Christ can become man, constantly changing man, without his divine nature changing. So, even when gaining or losing weight, or when going from standing to sitting, he fulfills the truth conditions for being immutable. And he fulfills the truth conditions for being mutable. He is both, but without contradiction. ${ }^{29}$

The next claim to consider is 8 , that Christ was crucified. To become crucified, Christ's human nature would have to go from fulfilling the ontological conditions in which a person with that nature is one way (not-crucified) to fulfilling the ontological conditions in which a person with that very nature is another way (crucified). Such an ontological story requires change in a human nature, just as the ontological story for the thieves at his right and left require change in different human natures. In all three cases, the human nature goes from having one inhering accident to having another, but no change in the divine nature is necessitated. Again, the revised notion of immutability is not contrary to incarnation.

Claim 9 is that Christ suffered. Does this render him not immutable? On the revised truth conditions, the answer is "no." True, suffering involves being affected, or perhaps being affected in a negative manner, as Christ was when he was crowned with thorns. That suffering, though, is explainable in terms of his human nature and the features it has, in much the same way being crucified is.

29 To see the logic of how such predications that are seemingly contradictory work on my view, see my "A Solution" and In Defense of Conciliar Christology. 
Claim 10 is that Christ died. What are the ontological aptness conditions for the predicate "died"? Perhaps we could say, as many in the tradition do, that for something to die is to have its animating soul separated from the matter that it informs. In such a case, Christ dies when his soul and body are separated. If that ontological condition is met, then it is true to say that Christ dies. But this death does not change the divine nature. And so again, we have no problem for incarnation and immutability. Think of it like this: mere humans die, but the ontological conditions for their deaths do not involve any change in the divine nature. We can explain the aptness conditions for predicating "dies" to mundane humans solely in terms of the relations between the body and soul that those mundane persons have. Likewise, then, for Christ.

What of claim 11, the claim of rising again? This is a predicate we can say of more than just Christ. Lazarus, for instance, rose again. On the ontology of human persons I have been assuming here, to rise again can be understood as having one's soul reanimate a body. For Lazarus, we can explain the whole case without recourse to anything divine in Lazarus, like a divine nature. Similarly for Christ, we can give the ontological conditions for resurrection without having to appeal to his divine nature.

What of claim 12, his ascension? The ascension took place by local motion of the body, at least in the first moments. (Do we know what happened next to the human nature after it was obscured by a cloud [Acts 1:6-11]?) To explain the local motion, we explain it in the way we explain any local motion of a typical human: the human moves through space, gaining or losing features as she goes. Likewise for Christ, he moved through space, gaining features (and altitude) as he went. It should be clear, though, that the changes he underwent were changes in his human nature, not his divine nature.

Finally, claim 13 is that Christ will come to judge the living and the dead. The ontological story here includes some aspects not revealed to us. But whatever those aspects are, there is no reason to believe that they will include the divine nature's going from being one way to another. And so there is no reason to think this part of the Incarnation, still yet to come, is contrary to immutability.

In short, then, no incarnational aspect of the Nicene Creed requires us to claim that Christ is not immutable. And, in fact, as we have seen, the Nicene Creed itself includes anathemas for those who claim that Christ was subject to alteration or mutability (when referring 
to his divine begetting), but the Creed also states that Christ was mutable when incarnate.

In the next section, I go from treating these cases individually to a general theory of how to treat cases of incarnational change in Christ in a way that preserves divine immutability in the revised sense.

\section{A Theory from the Cases}

Building on the cases discussed in the previous section, I now develop some general strategies for dealing with different types of predications true of Christ. The first strategy is to distinguish between accidental and essential predications. This distinction is drawn in various ways, and one understanding of essential predications is modal:

\section{The Modal View:}

$\mathrm{O}$ is $\mathrm{F}$ essentially if and only if

$\mathrm{O}$ is $\mathrm{F}$ accidentally if and only if $\mathrm{o}$ is $\mathrm{F}$, and o does not lack $\mathrm{F}$ in any possible world in which it exists. ${ }^{30}$

$\mathrm{o}$ is $\mathrm{F}$, and o does not lack $\mathrm{F}$ in some possible world in which it exists.

But I mention this distinction (the modal view of the predications) only to leave it to one side, and I do this for a few reasons. First, I think it is not the best way of drawing the distinction between essential and accidental predications, since some predicates are traditionally taken to be accidental and yet had by a thing in any situation in which it exists. I am thinking of propria, the features of a thing that are not of its essence but do "flow from" its essence, such that just in virtue of having that essence the thing must be that way. ${ }^{31}$ The classic example

30 When I refer to possible worlds here, I mean ways that all of existence could have been. The reader can think of them as maximally complete and exhaustive stories, such that, if you were to tell the story to God, he could truthfully respond, "I can add nothing to that story without reiteration, and nothing you said involves anything impossible." Possible worlds are useful heuristics for modal reasoning, just as Venn diagrams are useful for categorical reasoning. The reader should have as much worry about the ontological commitments and import of possible worlds, when I discuss them here, as the reader has for Venn diagrams when discussed in an introduction to logic class.

31 See, for instance, Michael Gorman, "The Essential and the Accidental," Ratio 18, no. 3 (2005): 276-89. 
is risibility. Humans are risible, and necessarily so, but that is not an essential feature of humans. Rather, we are essentially rational, and that rationality brings with it a concomitant feature of risibility.

Furthermore, I think essential predicates are predicates that are apt of a thing by virtue of an essence a thing has, and not by any accidental features a thing has. It is true to say of me that I am human, and that is true because of the essence I have. I am sitting as I type this, and that is true of me, but due to some accidental features that I have, rather than to my essence. ${ }^{32}$ So, one reason I set this modal understanding of essential features to one side is that I think it mischaracterizes the distinction. It no doubt draws a useful distinction, but not a distinction that ought to be labeled the "essential/accidental" distinction. That distinction should have more to do with a thing's essence and accidents than with the modal resilience of the predicate as applied to the thing.

A second reason to set aside the modal distinction, a reason suitable even for those who disagree with me that the modal distinction is mislabeled, is that it does no good distinguishing work in this case. For, since the Word need not have become incarnate, every attribute he has in virtue of his Incarnation will be accidental to him on the modal understanding of the distinction. For instance, it is true that he is a true man, but that is an accidental predication on the modal understanding of the terms, since in at least one possible scenario, he did not become incarnate at all. Thus, anything true of Christ solely in virtue of being incarnate will be a truth that is contingent, and so it is accidental in the modal interpretation of the world. In the modal sense, then, this distinction will do no work in distinguishing the problematic cases.

What to put in the place of the modal distinction? In this article, I will draw on a Scholastic understanding of essences and accidents. In particular, I will understand "essence" as synonymous with "nature." Things have individual, distinct natures. My human nature or essence and yours are distinct. But the nature includes only that which is of our essence, that which is settled by our shared genus and difference. That is, while I may be bearded and you not, such attributes are not parts of our essences, since being bearded (or not) is not

32 I have worked out this view of the truth conditions for essential and accidental predications in more detail in section 2 of my third chapter in "A Thomistic Account of Truthmakers for Modal Truths" (PhD diss., St. Louis University, 2008) and in In Defense of Conciliar Christology, 60-62. 
determined by the genus and difference under which all humans fall. I will take the distinction between essential and accidental features in the following sense:

The Scholastic View:

$\mathrm{o}$ is F essentially if and only if $\quad \mathrm{O}$ is $\mathrm{F}$, and " $\mathrm{O}$ is $\mathrm{F}$ " is true merely in virtue of some essence (or other) had by o.

$\mathrm{O}$ is $\mathrm{F}$ accidentally if and $\mathrm{O}$ is $\mathrm{F}$, and " $\mathrm{O}$ is $\mathrm{F}$ " is not only if

true merely in virtue of some essence (or other) had by o.

On these definitions, Christ is human essentially, since that predication is true and it is true merely in virtue of some essence that Christ has: his human essence. "Christ is risible" is true accidentally, since Christ is risible but it is not true merely in virtue of an essence he has. Rather, on the traditional picture, it is true in virtue of some accident that he has. It is true that a woman's having a human nature will imply that it is true that she is risible. This might lead some to think that it is the human nature in virtue of which she is risible, and so the predication ought to be essential. In response, the "in virtue of" language I use here is not intended to include implication. It is meant to refer to that ontological bit in virtue of which the thing is that way. Similarly, it may be true that all things with the faculty of intellect are things with the faculty of will. So, having an intellect will imply having a will. Nevertheless, the thing in virtue of which "I have a will" is true is not my intellect, but my will. The same can be said in this case of essence and risibility.

A perhaps surprising point to make here is that, on the Scholastic view, some essential predicates can be lacked by the things of which we aptly predicate them. ${ }^{33}$ Christ is human, and that predicate is an essential predicate. Nevertheless, he might not have been, since it is not necessary that God create any human natures at all, and so it is

33 For helpful discussions of Thomistic views of essential predications, see Jeffrey Brower, Aquinas's Ontology of the Material World: Change, Hylomorphism, and Material Objects (New York: Oxford University Press, 2014), 291, 297-304; Gloria Frost, "Thomas Aquinas on the Perpetual Truth of Essential Propositions," History of Philosophy Quarterly 27, no. 3 (2010): 197-213. 
possible that there be no humans, and so possible that the Word is not human. On the modal understanding of essential and accidental predications, a true, essential predication that a thing could lack is a contradiction in terms. If a predication is essential, then it is true in all worlds in which the thing exists; if it is had but lackable, then it is true in at least one world, but false in at least one world too. The surprise is mitigated, though, if we couple this understanding of the distinction with the orthodox doctrine that Christ freely and gratuitously took on a new essence in the Incarnation. In such a case, what else would we expect than that that essence would make true of him different predications? Such predications fit the bill for being contingent, essential predications.

In short, we can think about the four types of predications I am discussing in this section in the following way.

Type of Predication:

Necessary, Essential:

Necessary, Accidental:

Contingent, Essential:

Contingent, Accidental:
Required Ontological Conditions: The predication is true at every world and is true merely in virtue of some essence (or other) had by the subject of that predication in every world.

The predication is true at every world and is not true merely in virtue of some essence (or other) had by the subject of that predication in every world.

The predication is not true at every world and, where true, is true merely in virtue of some essence (or other) had by the subject of that predication in that world.

The predication is not true at every world and, where true, is not true merely in virtue of some essence (or other) had by the subject of that predication in that world. 
These four types of true predications are defined to be exclusive and exhaustive - any true predication will be of one and only one type. I will focus on each type of predication with respect to Christ, show its ontological truth conditions, and argue that they do not require a change in the divine nature.

Consider these four types of predications and some Christological examples from the list of thirteen predications from the Nicene Creed above:

\begin{tabular}{|l|l|l|}
\hline & Essential & Accidental \\
\hline Necessary & $\begin{array}{l}\text { (3) Christ is true God } \\
\text { (4) Christ is consubstantial } \\
\text { with the Father }\end{array}$ & Nothing \\
\hline Contingent & $\begin{array}{l}\text { (7) Christ became man } \\
\text { ( }) \text { Christ is a mammal }\end{array}$ & $\begin{array}{l}\text { (8) Christ was cruci- } \\
\text { fied } \\
\text { (12) Christ ascended } \\
\text { into heaven }\end{array}$ \\
\hline
\end{tabular}

Consider first the top-right box. I write there that there are no true predications in which Christ has a necessary yet accidental feature. To see why, consider the following argument. No contingent accident would go in that box, since a contingent accident is one that is lacked in some possible world. And, if it is lacked in a possible world, then it is not necessary. Such accidents go in the bottom right box. Since the examples we are looking for are necessary yet accidents, they must be necessary accidents, otherwise known as propria. Does Christ have any propria with respect to his divine nature? (Propria due to his human nature would not count here, since none of that is necessary to him, as the Incarnation is not necessary to him.) It would seem not.

A proprium is an accidental feature that a thing has in virtue of its essence. Now, the divine Persons have no accidental features, at least if a Thomistic version of divine simplicity is true. So, if such a view of divine simplicity is true, Christ has no divine propria. But then, he has no necessary yet accidental features.

On the other hand, if one denies a Thomistic view of divine simplicity, then one could claim that the divine Persons are composed of substance and accident, and so claim that some features of Christ are not essential to him and yet are necessary to him. Even if one did this, though, the resultant features would not be anything particularly 
tied in to the Incarnation, for again, the Incarnation is contingent and these purported features are necessary. Moreover, since propria are necessary accidents had in virtue of a thing's nature, and since all three divine Persons share the same divine nature, whatever proprium one divine Person has would be had by the other divine Persons too. In such a case, what would be the utility of stating that such features, since they are had by all three divine Persons in all possible scenarios, are not essential to the persons? I see traditional reason to deny that anything goes in that box (from simplicity), and, even aside from that, reason to think there to be no motivation to put anything in that box. As so, I mark it as containing nothing.

Nevertheless, if someone thinks, say, that the divine nature is that in virtue of which Christ is God, and some other thing is that in virtue of which he is begotten, or only-begotten, then the first predication, "Christ is the only-begotten Son of God," could go in that box. If one said that, then that in virtue of which Christ is the only-begotten Son of God (that is, the divine nature and whatever the other thing is) would be the ontological conditions for the predication in question. ${ }^{34}$ Those conditions need not change in the Incarnation. For instance, just suppose the other bit is a mode, or a trope, or a property, or something like that. Then the thing in virtue of which "Christ is the only-begotten Son of God" is true is the nature and the mode together. Christ's becoming incarnate does not strip him of that mode. And even if it did, such an ontological stripping would not be a change in the divine nature; it would be a change in the mode. So it would not render divine immutability problematic. Even if one populated the top right box, then, it would not lead to problems for immutability and incarnation.

34 The other thing in question here need not be an accident, given the definition I have given of a necessary-accidental predication. But, then, why is not my definition of "accidental" misleading, just as I claimed the modal interpretation of "essential" is misleading? I claimed in that previous discussion that the truth conditions for essential predications should have something to do with essences. Why not think that the truth conditions for accidental predications should have something to do with accidents? In reply, "accident" is used in many ways. In one sense, it is a name of a category of being, and it is true that the extra ontological thing in question here need not fall under that category. But in another sense, the term, "accident," refers to something that is outside of the essence of a thing in question. And any other thing added here for necessary accidental predications would be an accident in that sense. I thank Mark Spencer for this question. 
Consider next the necessary-essential predicates, the top-left box of examples in the above table. These predications are true in virtue of the divine nature. That is, in truthmaker language, the divine nature is the truthmaker for the predications "Christ is true God" and "Christ is consubstantial with the Father." "35 Such predications do not require the divine nature to change. It does not, for instance, go from being had by the Father alone at an earlier time to being had by the Father and Son at a later time-to say that it does would be to run afoul to the Nicene anathemas cited earlier. Such claims, then, do not require the falsity of divine immutability. And no Christian who affirms a traditional view of the Incarnation would want to say that such views imply the falsity of the content of the original Nicene Creed, which contained those anathemas. Thus, no traditional Christian should say that the necessary-essential attributes of God are what makes the Incarnation and divine immutability inconsistent. ${ }^{36}$

Predications true of Christ in virtue of his divine nature are such that they do not change. Insofar as Christ always has that divine nature, it will always be the case that he is aptly predicated by the predicates true of him in virtue of that nature. Even the kenosis theorist should agree with these statements at the current level of generality. For, the sophisticated kenosis thinker will say that the predicates apt of Christ in virtue of his divine nature are not things like "omnipotent" and "omniscient," but rather things like "omnipotent-unless-incarnate" and "omniscient-unless-incarnate." ${ }^{37}$ Those

35 What of predicates like "is begotten"? Is the truthmaker again just the divine nature? The Father and Spirit have that same nature, and yet they are not begotten. Good question; wrong venue. If I were forced to gesture at a response to this question, which is most decidedly not concerning the compatibility of incarnation and immutability, I would note that truthmakers make true whole propositions. That same divine nature can make true multiple propositions about different entities. That is what is happening here. My claim is not that anyone who has that nature has "is begotten" apt of him. My claim is that the divine nature makes it true both that "Christ is begotten" and that "the Spirit is not begotten."

36 Again, at this point someone might object that the essential, necessary attributes of God include God's mutability, and so the essential, necessary attributes of God do make the conjunction of divine immutability and incarnation impossible. This, though, as I have noted earlier, is not the sort of objection I have my eye on in this article. This person is really arguing for the falsity of divine immutability based on her philosophy of God. Such an argument might have ramifications for my project, but they are later downstream.

37 Thomas V. Morris, The Logic of God Incarnate (Ithaca, NY: Cornell University 
things remain true of him even when incarnate. It is only if he divested himself of his divine nature entirely that we would be able to deny the predicates of him that are apt of him in virtue of that divine nature. Conciliar Christology precludes such a scenario. And so, generally speaking, whatever predicates are apt of Christ in virtue of his divine nature will be predicates that do not change. Thus, they will not be predicates that imply that the divine nature is not superduper immutable. Your hand remains hovering over the buzzer.

Third, consider the contingent-essential predicates. These are predicates apt of Christ in virtue of his assumed human nature, not predicates apt of Christ in virtue of his assumed human nature along with other ontological components he has, such as accidents. We have seen predications of these types previously in discussing the Nicene Creed. It is because he has assumed a nature that is as it is that he is aptly called a man. I include another predicate in the examples, the predicate "mammal."

The point to make about these essential predications made true by the assumed human nature is that their ontological truth conditions do not require a change in the divine nature. Since Christ does have an essence that makes it true that he is a mammal-his human nature-it follows that Christ fulfills the aptness conditions for being predicated by "Christ is a mammal" (the terms "essence" and "nature" traditionally co-refer on some of their disambiguations). We have said all this, though, without having to say anything about his divine nature, and without having to say anything that implies a change in the divine nature. Your hand remains hovering over the buzzer.

Finally, consider the bottom-right predications, taken from the Nicene Creed. Christ was born of the Virgin Mary, suffered under Pontius Pilate, was crucified, died, and was buried. Does any of this require a change in the divine nature? I argued that it does not in the previous section. Here, I think we can give a general account as to why. The truth conditions for many of the contingent-accidental predications apt of Christ are also apt of mere humans. And mere humans do not have a divine nature to do truth-making work for predications formed with those predicates. So a divine nature, whether static or changing, is not a needful thing to fulfill the truth conditions for such predications. Its presence, absence, mutability, or

Press, 1987), 97-101. 
immutability are not necessary conditions for the predicates in question to be apt of a thing. And so the predications in question do not entail a mutable divine nature.

\section{Conclusion}

In conclusion, I have considered a prima facie difficulty with conciliar Christology that stems primarily from the third and fourth ecumenical council-Ephesus and Chalcedon-but can be motivated even from the very first ecumenical creed of the undivided Church, the Nicene Creed.The problem is that the texts appear to claim that Christ is both immutable and changed. I then showed that the texts not only appear to say that Christ is immutable and changes; they in fact say that. Next, I distinguished three understandings of immutability, arguing that two of them are incongruent with the conciliar teachings. After that, I considered the claims made of Christ in the Nicene Creed and gave a piecemeal account of the truth conditions for those claims, arguing that none of them required change on the part of the divine nature. Finally, from the cases discussed from the Nicene Creed, I formed a general account of how to provide truth conditions for predications of four exhaustive types. I have provided from these types a strategy for responding to claims that immutability implies the falsity of an incarnation or that, equivalently, incarnation implies the falsity of immutability. 